\title{
Limitations of the use of concrete resistivity as an indicator for the rate of chloride-induced macro-cell corrosion
}

Hornbostel, Karla $^{a^{*}}$; Elsener, Bernhard ${ }^{\text {b,c }}$; Angst, Ueli Michael ${ }^{\text {b,d }}$; Larsen, Claus Kenneth ${ }^{\text {a,e }}$ and Geiker, Mette Rica ${ }^{a}$

\footnotetext{
${ }^{a}$ Norwegian University of Science and Technology, Department of Structural Engineering, Norway

${ }^{\mathrm{b}}$ ETH Zurich, Institute for Building Materials (IfB), Switzerland

${ }^{\mathrm{c}}$ University of Cagliari, Department of Chemical and Geological Science, Italy

${ }^{\mathrm{d}}$ Swiss Society for Corrosion Protection (SGK), Switzerland

${ }^{\mathrm{e}}$ Norwegian Public Roads Administration, Norway

* Corresponding author:

Richard Birkelandsvei 1a, 7491 Trondheim, Norway, Tel.: +47 73594537, E-mail address: Karla.Hornbostel@ntnu.no
}

\begin{abstract}
An experimental setup was designed to study the impact of concrete resistivity on the rate of chloride-induced reinforcement corrosion. Small pieces of mild steel were used to simulate pits (anodes) that form when chlorides come into contact with the reinforcement. The galvanic current was measured between the simulated anodes and a cathode network. Comparisons were made between the galvanic current and the concrete bulk resistivity. The bulk resistivity was varied using two mortar mixes (made of plain Portland cement and a blended Fly ash cement) which were exposed in different temperature and moisture conditions. Despite a high scatter in the results, it was clear that the relationship between bulk resistivity and corrosion rate depended on the mortars tested. The findings presented in this paper and the accompanying work strongly indicate that concrete bulk resistivity alone does not provide sufficient information for assessment of the corrosion rate for chloride-induced macro-cell corrosion.
\end{abstract}




\section{Introduction}

Reinforcement corrosion in concrete due to chlorides causes costly damage and is considered one of the greatest infrastructure problems [1, 2]. Chloride-induced corrosion typically consists of a local corrosion attack with small areas of anodic activity (pits) surrounded by a large passive/cathodic area (Figure 1). Acidification takes place in the pits leading to iron dissolution (anodic partial process). The electrons released are consumed by a cathodic reaction (mostly oxygen reduction) on the passive steel surface (cathodic partial process). To equilibrate the half-cell reactions, current flows between the anode and the cathode through the concrete (ohmic partial process) as well as through the steel. The overall rate of the corrosion process depends on the rates of the anodic, cathodic and ohmic partial processes, the slowest of them being rate-limiting.

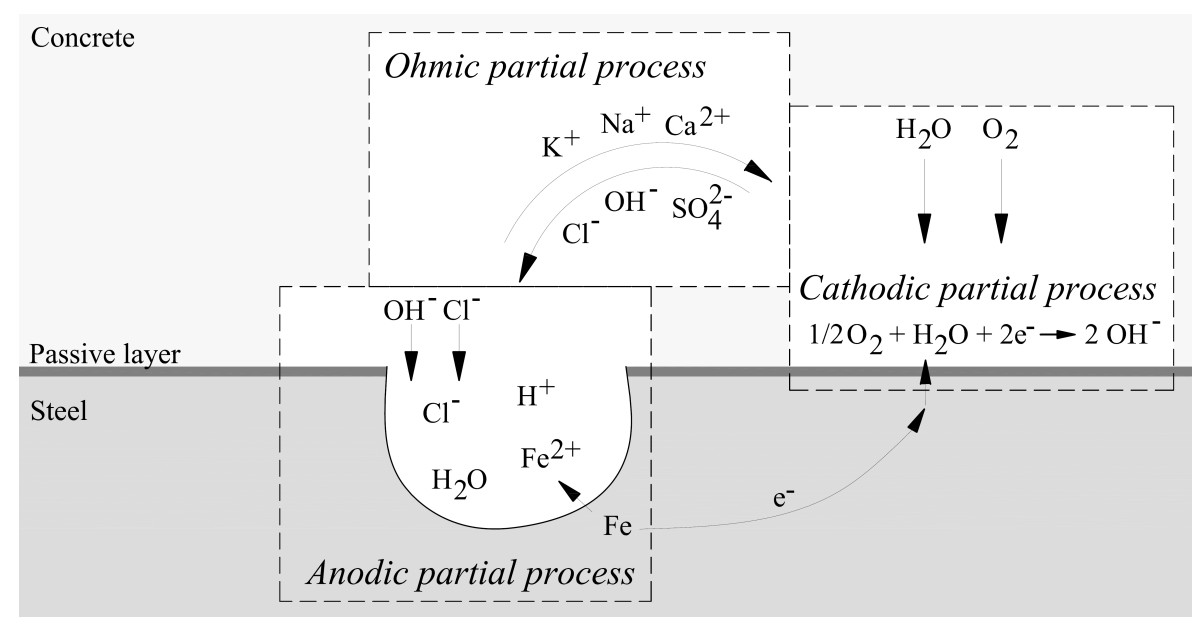

Figure 1 - The electrochemical process of reinforcement corrosion induced by chlorides $[1,3]$.

There are various ways of determining the overall rate of the corrosion process. Electrochemical methods are commonly used both in experimental studies and in the field. However, they are subject to several sources of error [4-8]. 
Simplified approaches for predicting the corrosion rate through an empirical relationship with the concrete resistivity have been proposed in the literature [9-11]. A literature review on this subject was prepared by three of the present authors [12]. Data and trends from the literature are summarized in Figure 2.

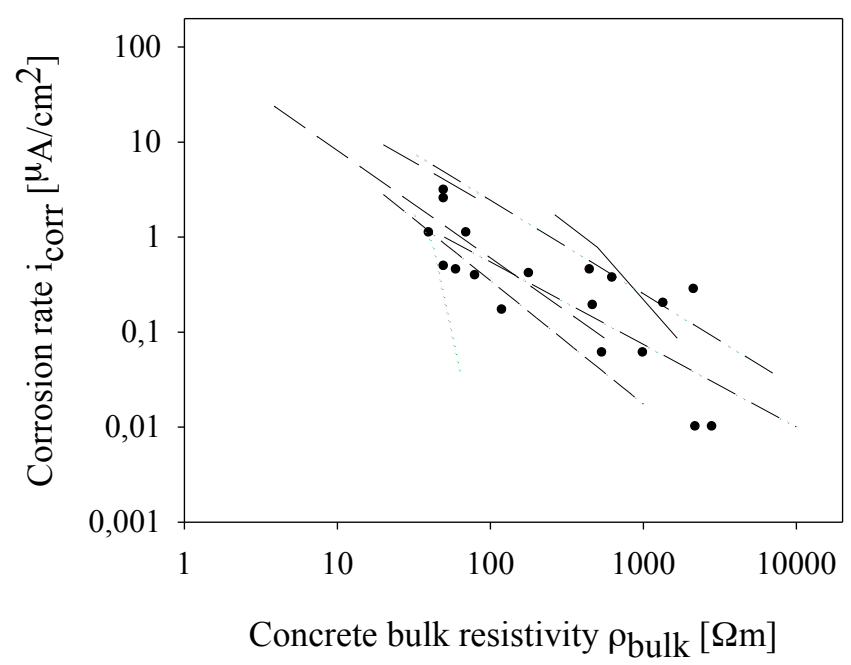

\begin{tabular}{|c|c|}
\hline - & (Rodriguez et al. 1994) - field data \\
\hline & $\begin{array}{l}\text { (Bertolini et al. } 1997 \text { ) }-0.45 \text {, slag ce } \\
\text { (Bertolini et al. 1997) }-0.45 \text {, OPC }\end{array}$ \\
\hline------ & (Morris et al. 2002) - 0.4/0.6 \\
\hline$-\cdots-\cdots-\cdots-$ & (Gonzalez et al. 2004)- 0.5 \\
\hline-- & (Hope et al. 1987) -0.45 , slag cements \\
\hline$-\ldots-\ldots$ & (Lopez et al. 1993) - 0.5 \\
\hline$-\ldots-$ & (Feliu et al. 1989) -0.5 \\
\hline
\end{tabular}

Figure 2 - Trend lines for the relationship between corrosion rate and concrete resistivity (chloride-induced corrosion) from published literature [12-20].

The main conclusion of this literature review [12] was that while there does seem to be a general trend between increasing concrete resistivity and decreasing corrosion rate, the scatter within and between the various studies reviewed is high. It was suggested that the differences were partly caused by the different methodologies for determining concrete resistivity and corrosion rate and partly by the concrete composition. The literature reviewed contained limited discussion on the mechanisms that might underlie any direct correlation between concrete resistivity and corrosion rate. 
Understanding the impact of concrete resistivity on the rate of chloride-induced reinforcement corrosion is relevant for both durability design and the assessment of existing structures. The relationship between concrete resistivity and corrosion rate has been further investigated using an experimental setup that simulates chloride-induced macro-cell corrosion. Results from the investigation are summarized in this paper.

\section{Experimental}

An experimental setup was designed using small pieces of mild steel to simulate pits (anodes) formed due to chloride-induced corrosion. The simulated anodes were located in a network of stainless steel tubes and bars that acted as cathode (the setup is sketched in Figure 3). The experimental setup, materials and exposure are described below; details can also be found in $[21]$.

\subsection{Experimental setup}

The simulated anodes were produced from a smooth mild steel bar cut into small pieces (S235JR Ø $6 \mathrm{~mm}$, length $\sim 6 \mathrm{~mm}$ ). The mild steel pieces were sandblasted and coated with heat-shrink tubing leaving just one cut surface exposed (exposed area $28.3 \mathrm{~mm}^{2}$ ). To enhance the portability of corrosion onset, four mild steel pieces were mounted in one stainless steel tube (denoted C1, AISI 316, Ø $12 \mathrm{~mm}$, exposed area $4270 \mathrm{~mm}^{2}$ ). The stainless steel tube and the mild steel pieces were electrically isolated from another. This instrumented tube and additional four stainless steel bars (denoted C1-1, C1-2, C2-1, C2-2, AISI 316L, Ø 10 mm, exposed area $3770 \mathrm{~mm}^{2}$ for each cathode bar) were placed at various distances from the simulated anodes. Simulated anodes and all cathodes were equipped with wires to allow 
manually connections between them. A manganese dioxide reference electrode (ERE 20, Force Technology) was embedded in each specimen.

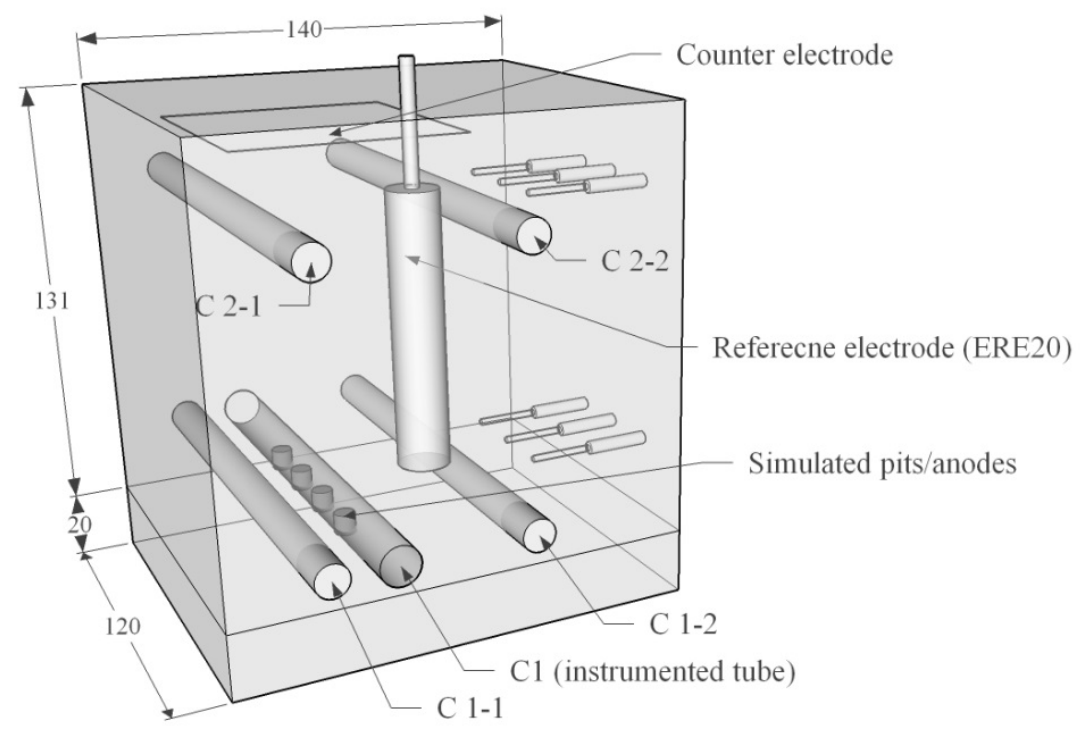

Figure 3 - Experimental setup [21], the samples were exposed to chlorides from the lower surface of the specimen..

\subsection{Materials and exposures}

Mortar specimens were prepared using two mortar mixes: a low-resistivity mix (with a water/binder ratio $(\mathrm{w} / \mathrm{b})=0.55$ using only Portland cement $(\mathrm{CEM}$ I $42.5 \mathrm{R}))$ denoted PC, and a high-resistivity mix (with a w/b $=0.4$ in which $30 \%$ of the Portland cement was replaced by fly ash) denoted FA.

The mortar specimens were cured by sealing for several weeks (PC mortars 4 weeks, FA mortars 18 weeks $)$ in a climate chamber $\left(20^{\circ} \mathrm{C}\right)$ and then exposed to various environments, starting with a few weeks of exposure to a chloride solution, followed by a sequence of different temperature and moisture conditions (Table 1 and Table 2). The FA and PC specimens were not exposed to exactly the same conditions. The main aim of the exposure treatment was to achieve a large range of bulk resistivity. It was not within the scope of this 
experiment to study the influence of moisture or temperature nor time on the corrosion process.

Table 1 - Exposure conditions PC specimens ( 9 specimens in total).

\begin{tabular}{|c|c|c|c|c|}
\hline Exposure & \multicolumn{3}{|c|}{ Temperature } & Weeks after Casting \\
\hline Casting & \multicolumn{3}{|c|}{$20^{\circ} \mathrm{C}$} & 1 \\
\hline Curing (sealed, $20^{\circ} \mathrm{C}$, climate room) & \multicolumn{3}{|c|}{$20^{\circ} \mathrm{C}$} & $2-4$ \\
\hline Drying (oven) & \multicolumn{3}{|c|}{$30^{\circ} \mathrm{C}$} & $5-8$ \\
\hline Storage (laboratory) & \multicolumn{3}{|c|}{$20^{\circ} \mathrm{C}$} & 9 \\
\hline Exposure to $3 \mathrm{~mol} / \mathrm{L} \mathrm{NaCl}$ solution & $5^{\circ} \mathrm{C}$ & $20^{\circ} \mathrm{C}$ & $35^{\circ} \mathrm{C}$ & $10-17$ \\
\hline Stored in closed boxes $(\mathrm{RH} \sim 85 \%)$ & $5^{\circ} \mathrm{C}$ & $20^{\circ} \mathrm{C}$ & $35^{\circ} \mathrm{C}$ & $18-43 *$ \\
\hline Stored in closed boxes $(\mathrm{RH} \sim 85 \%)$ & \multicolumn{3}{|c|}{$20^{\circ} \mathrm{C}$} & 44 \\
\hline Storage (laboratory) & \multicolumn{3}{|c|}{$20^{\circ} \mathrm{C}$} & $45-53$ \\
\hline Stored in closed boxes $(\mathrm{RH} \sim 30 \%)$ & \multicolumn{3}{|c|}{$20^{\circ} \mathrm{C}$} & $54-91 *$ \\
\hline Exposure to tap water & \multicolumn{3}{|c|}{$20^{\circ} \mathrm{C}$} & $92 *$ \\
\hline Stored in closed boxes $(\mathrm{RH} \sim 85 \%)$ & $5^{\circ} \mathrm{C}$ & $20{ }^{\circ} \mathrm{C}$ & $35^{\circ} \mathrm{C}$ & $93 *$ \\
\hline Storage (laboratory) & \multicolumn{3}{|c|}{$20^{\circ} \mathrm{C}$} & $94^{*}$ \\
\hline
\end{tabular}

* measurements presented in the paper

Table 2 - Exposure conditions FA specimens ( 9 specimens in total).

\begin{tabular}{|c|c|c|c|c|}
\hline Exposure & \multicolumn{3}{|c|}{ Temperature } & Weeks after Casting \\
\hline Casting & \multicolumn{3}{|c|}{$20^{\circ} \mathrm{C}$} & 1 \\
\hline Curing (sealed, $20^{\circ} \mathrm{C}$, climate room) & \multicolumn{3}{|c|}{$20^{\circ} \mathrm{C}$} & $2-20$ \\
\hline Drying (oven) & \multicolumn{3}{|c|}{$30^{\circ} \mathrm{C}$} & $21-23$ \\
\hline Storage (laboratory) & \multicolumn{3}{|c|}{$20^{\circ} \mathrm{C}$} & 24 \\
\hline Exposure to $3 \mathrm{~mol} / \mathrm{L} \mathrm{NaCl}$ solution & $5^{\circ} \mathrm{C}$ & $20{ }^{\circ} \mathrm{C}$ & $35^{\circ} \mathrm{C}$ & 25 \\
\hline Stored in closed boxes $(\mathrm{RH} \sim 85 \%)$ & $5^{\circ} \mathrm{C}$ & $20^{\circ} \mathrm{C}$ & $35^{\circ} \mathrm{C}$ & $26-54 *$ \\
\hline Stored in closed boxes $(\mathrm{RH} \sim 85 \%)$ & \multicolumn{3}{|c|}{$20^{\circ} \mathrm{C}$} & $55-87$ \\
\hline Storage (laboratory) & \multicolumn{3}{|c|}{$20^{\circ} \mathrm{C}$} & $88-92 *$ \\
\hline Exposure to $3 \mathrm{~mol} / \mathrm{L} \mathrm{NaCl}$ solution & \multicolumn{3}{|c|}{$20^{\circ} \mathrm{C}$} & $93 *$ \\
\hline Stored in closed boxes $(\mathrm{RH} \sim 85 \%)$ & $5^{\circ} \mathrm{C}$ & $20{ }^{\circ} \mathrm{C}$ & $35^{\circ} \mathrm{C}$ & $94 *$ \\
\hline Storage (laboratory) & \multicolumn{3}{|c|}{$20^{\circ} \mathrm{C}$} & $95^{*}$ \\
\hline
\end{tabular}

* measurements presented in the paper

\subsection{Methods of investigation}

After corrosion initiation (indicated by potential drops), detailed measurements were undertaken for just one simulated anode per specimen. The remaining three simulated anodes 
were isolated. The selected simulated anode was manually connected to all cathodes during the whole study (C1, C1-1, C1-2, C2-1, C2-2, cf. Figure 3, cathode-to-anode area ratio 685.).

\subsubsection{Bulk resistivity and cell resistance}

The bulk resistivity $\left(\rho_{\text {bulk }}\right)$ of the mortars on the level of the instrumented bar was determined by measuring the electrical resistance between the stainless steel bar (C1-2) and the instrumented tube (C1 - only tube without simulated anodes) using an LCR meter (frequency $1 \mathrm{kHz})$, and by applying a pre-calibrated cell constant $(0.142-0.187 \mathrm{~m})$.

The electrical resistance between the simulated anode and the cathode network, termed cell resistance $\left(\mathrm{R}_{\text {cell }}\right)$ in the following, was measured with electrical impedance spectroscopy (EIS), using a potentiostat of the type PRINCETON APPLIED RESEARCH PARSTAT 2273. The cell resistance depends not only on the geometry (anode and cathode size) and the bulk resistivity, but also on material inhomogeneities in front of the anode. This is in detailed described in an earlier publication [22].

\subsubsection{Galvanic current and corrosion rate}

The galvanic current $\left(I_{\text {galv }}\right)$ between the simulated anode and the cathode network was measured using a zero-resistance ammeter.

The overall corrosion rate was calculated by dividing the galvanic current by the total exposed area of the simulated anode $\left(28.3 \mathrm{~mm}^{2}\right)$. The amount of micro-cell corrosion (cathodic reactions occurring on the simulated anode) and the amount of non-corroded areas on the simulated anode were consequently disregarded. 
Some of the specimens were opened after finishing the tests. The volume loss on the steel pieces (simulated anodes) after removing all corrosion products, was determined using 3D scanning and compared with the volume loss calculated on basis of the galvanic current measurements (details are given in [23]). The differences between the actual volume loss determined on the segments and the calculations from the galvanic current measurements was assumed to account for the extent of self-/microcell-corrosion. The results indicate limited micro-cell corrosion on the PC specimens, but a rather high degree (some 40-70\%) of microcell corrosion on the FA specimens. This suggests that the corrosion rate of the anodes calculated here is adequate for the PC specimens, but underestimates the actual corrosion rate for the FA specimens. The results for the FA specimens were not corrected because the actual amount of micro-cell corrosion will vary depending on e.g. the magnitude of the galvanic current [24]. Nevertheless, it is indicated in the figures as well as mentioned in the following discussions that the actual corrosion rate of the anodes are likely to be higher for the FA specimens.

In general, the corrosion process had propagated considerably more in the PC specimens than in the FA specimens. This is presumably a combined effect of the different exposure and material properties.

\section{Results}

The instantaneous corrosion rate calculated from the galvanic current measurements was compared with the bulk resistivity (Figure 4 a)) and the cell resistance (Figure 4 b)). In Figure 4 a), the data and trend lines derived from the literature (cf. literature review [12]) are indicated by light grey symbols and lines (cf. Figure 2). It is clear that the corrosion rates determined in the present study are considerably higher than those reported in the literature. 
Moreover, the data for the two mortar compositions investigated appear in two clearly separated groups. The data shows significant scatter and no linear relationship in the log-log diagram. When the corrosion rate is compared with the cell resistance instead of bulk resistivity, the impact of the mortar composition becomes less pronounced (cf. Figure $4 \mathrm{~b}$ )). A linear relationship appears in the log-log diagram, but the data shows significant scatter also here.

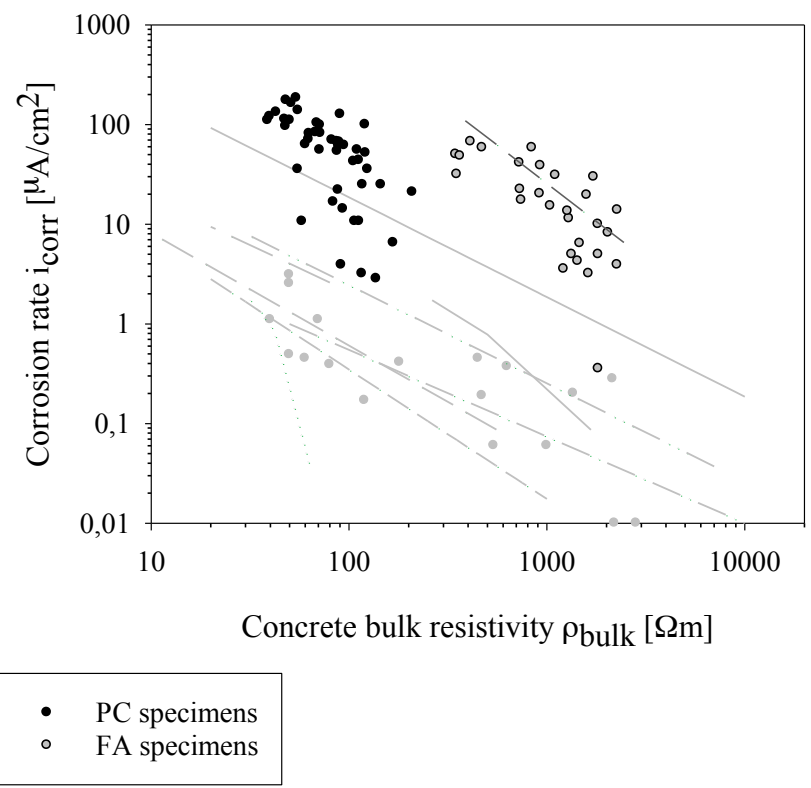

a)

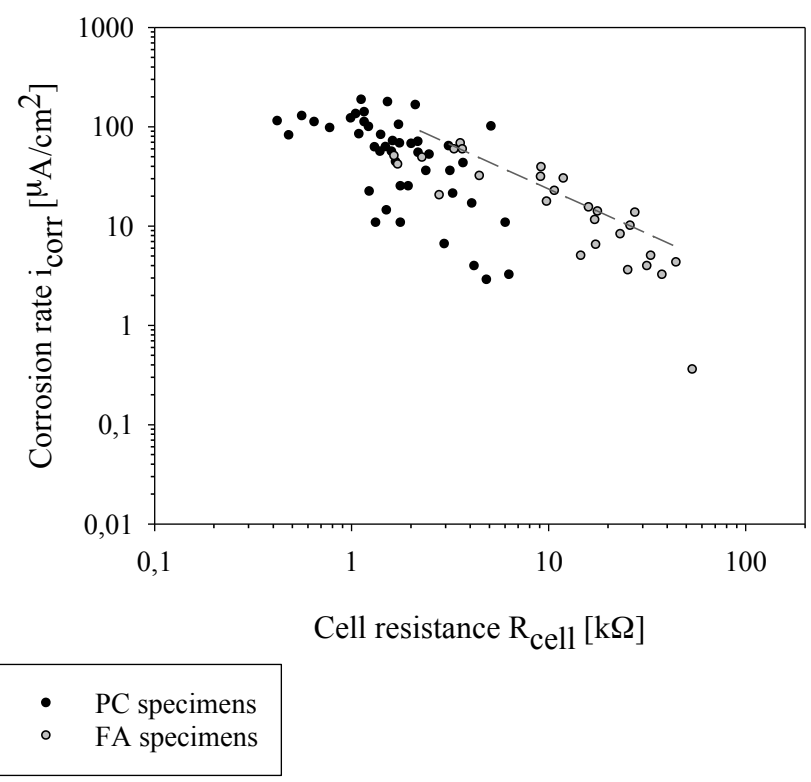


b)

Figure 4 - Comparison of the instantaneous corrosion rate calculated based on galvanic current measurements and a) the bulk resistivity, and b) the cell resistance after [21]. The dashed grey line indicates the position of the overall trend for the data of the FA specimens taking into account an increase in the corrosion rate due to selfcorrosion (factor of two) - see also explanations in the text.

It should be remembered that micro-cell corrosion was deduced on anodes of the FA specimens. Consequently, the corrosion rate calculated from the galvanic current measurements underestimates the actual corrosion rate. This is taken into account by adding a dark grey dashed line in both graphs (Figure 4 a) and b)) to indicate the trend of the presumably higher corrosion rates for the FA specimens.

\section{Discussion}

\subsection{Relationship between corrosion rate and concrete resistivity}

\subsubsection{Dependency on mortar composition}

The data for the comparison between bulk resistivity and calculated corrosion rate (Figure 4 a)) differs for the two mortar compositions (w/b=0.55, PC vs. w/b=0.4, PC+FA). This is in line with observations by Bertolini and Polder [14] who report that although concrete with a certain amount of slag exhibited one order of magnitude higher resistivity than concrete made of PC, the corrosion rates differed less than the resistivity. This corresponds to a change in the trends for the relationship between concrete resistivity and corrosion rate for the two different mortars tested (cf. Figure 2, data from [14]).

Concretes containing supplementary cementitious materials, such as fly ash, silica fume or slag, typically exhibit a lower $\mathrm{pH}$ in the pore solution and a denser pore structure $[25,26]$. This explains the higher resistivity of mixes prepared with supplementary cementitious materials. However, a decrease in the $\mathrm{pH}$ of the pore solution can favour higher corrosion rates, which has been demonstrated with reinforcing steel in simulated pore solution [27, 28]. 
For a pore solution with constant chloride concentration, the corrosion rate increased with decreasing $\mathrm{pH}$, i.e. increasing pore solution resistivity [27]. In the same study, solutions with a constant $\mathrm{pH}$ and differing chloride concentration exhibited distinctly different relationships between pore solution resistivity and the corrosion rate. Despite differences in resistivity, a solution with low $\mathrm{pH}(11.64-12.66)$ exhibited the same corrosion rate as a solution with high $\mathrm{pH}$ (12.8-13.0). This corresponds to the observed differences for the relationship between the bulk resistivity and the corrosion rate for the PC and FA mortars in the present study. No measurements of the $\mathrm{pH}$ in the pore solution were undertaken during the experiment. However, in an investigation using similar raw materials and mortar compositions, specimens prepared with $\mathrm{PC}$ showed a constant $\mathrm{pH}$ of 13.7 during the 140 days of investigation, whereas for mortars with $35 \%$ of PC replaced with fly ash, the $\mathrm{pH}$ decreased continuously from 13.6 to 13.3 [29]. Presumably, the $\mathrm{pH}$ was even lower in the FA specimens investigated in the present study because they were tested over a longer period ( $\sim 670$ days). However, observations from pore solutions are not directly transferable to the corrosion kinetics in concrete. In addition to pore solution chemistry, a range of other parameters influence the corrosion rate, e.g. pore volume and connectivity. Differences in pore structure are presumably among the main reasons for the average corrosion rate of anodes in the FA mortars being lower than in the PC mortars.

Variations in the $\mathrm{pH}$ of the pore solutions are one possible explanation for the shifted trends in the relationship between corrosion rate and bulk resistivity for the PC and FA mortars. The data showed that steel embedded in a high-resistivity concrete (made of supplementary cementitious materials exhibiting lower $\mathrm{pH}$ in the pore solution) will not necessarily corrode at a lower rate than steel embedded in low-resistivity concretes. 


\subsubsection{Rate-limiting step}

A considerable scatter was observed in the relationship between corrosion rate and bulk resistivity/cell resistance in the data sets of the two mortars tested. In fact, the scatter in corrosion rate ranged over two orders of magnitude for a given mortar resistivity or cell resistance (cf. Figure 4). This might be explained by differences in the rate-limiting step that controls the corrosion process (cf. Figure 1). The rate-limiting step differs depending on a variety of parameters, such as moisture content, stage of corrosion propagation, oxygen availability and geometry [14, 30-37].

The influence of bulk resistivity or cell resistance on the partial processes is discussed in another publication of the present authors [21]. From the experiments, a rather poor correlation between mortar resistivity and the cathodic partial process (both Tafel constant $\beta \mathrm{c}$ and exchange current density) was obtained, which agrees well with findings in the literature $[21,37,38]$. Both the anodic and the ohmic partial processes showed a partial correlation with the bulk resistivity. A somewhat improved correlation was found with the cell resistance, indicating that, for the anode size tested here, local conditions are more decisive for the anodic and ohmic partial process than the bulk resistivity. However, here too a quite high scatter was obtained (cf. Figure 4 b)), which indicates that other parameters, not related to the electrical properties of the mortar matrix, affect the partial processes. For the anode size and cathode-to-anode ratio tested here, it was shown that none of the three partial processes alone, but rather a combination of all three, dominates the corrosion process [21]. This suggests that bulk resistivity alone cannot characterize the corrosion rate.

The previously cited investigation [21] also discusses to what extent the dimensions of the tested specimens influences the rate-limiting step and consequently the corrosion rate. It is 
suggested that with increasing sample size and for large-scale structures, the influence of the ohmic partial process may increase while cathodic reaction-rate-related properties will be less important [21]. This would imply that concrete resistivity can, under certain conditions (e.g. large structures with infinitively large cathodic area and low resistance of the anodic partial process), be more clearly related to the corrosion rate than was found in the present smallscale experiments. However, data reported by Rodriguez and co-workers [13] from field measurements had by far the highest scatter of all the data reviewed in [12] (cf. Figure 2). Both findings suggest that the influence of the ohmic partial process (and the concrete resistivity) for large-scale structures with an infinitely large ratio between cathode and anode needs further attention.

\subsection{Concrete/mortar resistivity}

Concrete/mortar is an inhomogeneous material and typically regarded as biphasic from an electrical point of view, with non-conductive aggregates surrounded by conductive cement paste $[39,40]$. In most resistivity measurements, a large material volume is enclosed by the current field applied; consequently, what is measured is an average of a variety of individual electrical properties. However, in cases where the measurements cover just a small area, comparable in size to aggregates and voids (e.g. for the current flow between small anodes and a large cathode network, cf. 'cell resistance'), the respective electrical properties of the inhomogeneities are of great importance. This was investigated in an experimental study conducted by the present authors [22], where dimensions comparable to the presented study were used. It was found that the cell resistance is not directly correlated to the bulk resistivity, a fact which was explained by the influence of possible inhomogeneities located in front of the simulated anodes. 


\subsection{Corrosion rate measurements}

Quantitative information on the corrosion rate of steel in concrete is of great importance for (residual) service life prediction, assessment of corroding structures, and for the evaluation of repair methods both in the laboratory and in the field [41]. As input into models for lifetime prediction, what is required is the average corrosion rate as an 'engineering' value. Values calculated from the observed loss of cross-section of the steel (on site) are usually erroneously estimated, because the time of depassivation (time when corrosion started) is not known. On the other hand, the instantaneous corrosion rate, $\mathrm{i}_{\text {corr, }}$ can be obtained using various electrochemical methods. The linear polarization technique (LPR) is often used. This links the polarization resistance $\left(\mathrm{R}_{\mathrm{p}}\right)$ to the corrosion rate $\left(\mathrm{i}_{\text {corr }}\right)$ by the well-known Stern-Geary equation [42]. However, it has recently been shown that the Stern-Geary equation cannot be used for localized corrosion [4]. Furthermore, the fact that the area of the locally corroding spot is generally unknown is a practical limitation with this approach, as has been discussed in literature [41]. Experimental data from both laboratory and on-site measurements have shown that the real, local corrosion rates are 5 to 10 times higher than the values determined when relating $\mathrm{R}_{\mathrm{p}}$ to the geometric area of the sample [43]. This huge difference can be taken into account by including a (somewhat arbitrary) 'pitting factor' in the calculations. Factors between 4 and 8 are reported for steel in concrete $[44,45]$, however the examination of pit depths in old RC structures have led to values greater than 10 [43], and laboratory experiments with model macro-cells have resulted in factors as high as 15 [46].

In this research, the area of local corrosion was known (cf. Section 2.3.2), and the galvanic current measured between local anode and the cathode network can be considered a true measure of the instantaneous corrosion rate. But the fact remains that the corrosion rates

determined are considerably higher than is reported in the literature (Figure 4 a)). This 
discrepancy can be explained by the small corroding area in this research compared to the total steel area. The trend lines depicted in Figure 2 and Figure 4 a) are based on experimental investigations, where the corrosion rate was determined by dividing the measured corrosion current (e.g. by Liner Polarisation Resistance (LPR)) by the entire exposed steel area (detailed information is given in [12]); this would lead to a difference of the above-mentioned factor of 5-10. Another reason for the observed high corrosion rates is that a 'worst case scenario' was tested in the present experiment, with presumably high chloride contents at the reinforcement (not tested here), pre-dried concrete microstructure, and favourably high relative humidity, which all facilitate high corrosion activity.

The differences observed indicate that the actual corrosion rate can be considerably underestimated when the corrosion current measured is normalized to an area larger than the actual actively corroding area. This also means that the comparability of studies in which different-sized areas are polarized by the electrochemical measurements becomes questionable, because this alone could explain the differences observed between the studies compared in Figure 2.

\section{Conclusions}

The applicability of using bulk resistivity as an indirect measure of corrosion rate was investigated using a custom-made experimental setup simulating chloride-induced macro-cell corrosion. Mortar specimens with and without fly ash were investigated.

An inverse trend of increasing corrosion rate with decreasing bulk resistivity was observed for both mortars tested. However, the material composition was found to affect the trend between bulk resistivity and the rate of chloride-induced macro-cell corrosion. Steel embedded in a 
high-resistivity mortar (made of supplementary cementitious materials exhibiting lower $\mathrm{pH}$ in the pore solution) will not necessarily be corroded at a lower rate than steel embedded in lowresistivity (OPC) mortar.

A high scatter was observed in the data for similar mortar composition. This was explained by

a) the bulk resistivity not representing the actual ohmic resistance in the macro-cell, and b) not only ohmic, but in part also anodic and cathodic control of the corrosion process.

In conclusion, the bulk resistivity can only provide a rough indication of the corrosion rate, but it can in no case be used as an indirect measure of the actual corrosion rate for chlorideinduced macro-cell corrosion.

\section{Acknowledgements}

The paper is based on work carried out at the NTNU, Trondheim and in COIN - the Concrete Innovation Centre (www.coinweb.no) - a centre for research-based innovation, which was initiated by the Research Council of Norway (RCN) in 2006 and supported by the Norwegian Public Roads Administration (www.vegvesen.no). The 3D scanning was undertaken by Cascade AB, Sweden. The images were analysed by Trine-Lise Lorentsen. Special thanks to Kristian Sætre and Miguel Boix Roca for their help with the experimental work.

\section{References}

1. $\quad$ Bertolini, L., et al., Corrosion of Steel in Concrete: Prevention, Diagnosis, Repair (2nd Edition). 2013: Wiley-VCH Verlag GmbH \& Co.

2. $\quad$ Broomfield, J.P., Corrosion of steel in concrete: understanding, investigation, and repair. 1. ed. 1997, London and New York: E \& FN Spon. xxi, 240 p.

3. Angst, U., Chloride induced reinforcement corrosion in concrete - Concept of critical chloride content methods and mechanisms, Doctoral Thesis, in Department of Structural Engineering. 2011, Norwegian University of Science and Technology: Trondheim. 
4. Angst, U. and M. Büchler, On the applicability of the Stern-Geary relationship to determine instantaneous corrosion rates in macro-cell corrosion. Materials and Corrosion-Werkstoffe und Korrosion, 2014. doi: 10.1002/maco.201407997.

5. Andrade, C., et al., On-site corrosion rate measurements: $3 D$ simulation and representative values. Materials and Corrosion-Werkstoffe und Korrosion, 2012. 63(12): p. 1154-1164.

6. Kranc, S.C. and A.A. Sagüés, Polarization Current Distribution and Electrochemical Impedance Response of Reinforced-Concrete When Using Guard Ring Electrodes. Electrochimica Acta, 1993. 38(14): p. 2055-2061.

7. Nygaard, P.V., M.R. Geiker, and B. Elsener, Corrosion rate of steel in concrete: evaluation of confinement techniques for on-site corrosion rate measurements. Materials and Structures, 2009. 42(8): p. 1059-1076.

8. Nygaard, P.V. and M.R. Geiker, Measuring the corrosion rate of steel in concrete - effect of measurement technique, polarisation time and current. Materials and Corrosion-Werkstoffe und Korrosion, 2012. 63(3): p. 200-214.

9. Broomfield, J. and S. Millard, Measuring concrete resistivity to assess corrosion rates. Concrete, 2002. 36(2): p. 37-39.

10. Ahmad, S., An experimental study on correlation between concrete resistivity and reinforcement corrosion rate. Anti-Corrosion Methods and Materials, 2014. 61(3): p. 158-165.

11. Andrade, C. and R. d'Andrea, Electrical resistivity as microstructural parameter for the modelling of service life of reinforced concrete structures, in 2nd International Symposium on Service Life Design for Infrastructure, K.v. Breugel, G. Ye, and Y. Yuan, Editors. 2010, RILEM Publications S.A.R.L.: Delft, The Netherlands. p. 379-388.

12. Hornbostel, K., C.K. Larsen, and M.R. Geiker, Relationship between concrete resistivity and corrosion rate - A literature review. Cement and Concrete Composites, 2013. 39: p. 60-72.

13. Rodriguez, J., et al., On site corrosion rate measurements in concrete structures using a device developed under the eureka project EU-401, in International Conference on Concrete Across Borders 1994: Odense, Denmark p. 215-226.

14. Bertolini, L. and R.B. Polder, Concrete resistivity and reinforcement corrosion rate as a function of temperature and humidity of the environment. TNO report 1997: TNO Building and Construction Research.

15. Morris, W., et al., Corrosion of reinforcing steel evaluated by means of concrete resistivity measurements. Corrosion Science, 2002. 44(1): p. 81-99.

16. González, J.A., J.M. Miranda, and S. Feliu, Considerations on reproducibility of potential and corrosion rate measurements in reinforced concrete. Corrosion Science, 2004. 46(10): p. 2467-2485.

17. Hope, B.B. and A.K.C. Ip, Corrosion of Steel in Concrete Made with Slag Cement. ACI Materials Journal, 1987. 84(6): p. 525-531.

18. López, W. and J.A. González, Influence of the Degree of Pore Saturation on the Resistivity of Concrete and the Corrosion Rate of Steel Reinforcement. Cement and Concrete Research, 1993. 23((2)): p. 368376.

19. Feliu, S., et al., Relationship between conductivity of concrete and corrosion of reinforcing bars. British Corrosion Journal, 1989. 24(3): p. 195-198.

20. DuraCrete, DuraCrete - Probabilistic Performance based Durability Design of Concrete Structures. 2000, The European Union - Brite EuRam III.

21. Hornbostel, K., et al., Influence of mortar resistivity on the rate-limiting step of chloride-induced macro-cell corrosion of reinforcing steel. Corrosion Science, 2016. in Press.

22. Hornbostel, K., et al., On the limitations of predicting the ohmic resistance in a macro-cell in mortar from bulk resistivity measurements. Cement and Concrete Research 2015. 76: p. 147-158.

23. Hornbostel, K., The role of concrete resistivity in chloride-induced macro-cell corrosion of reinforcement, Doctoral Thesis, in Department of Structural Engineering. 2015, Norwegian University of Science and Technology (NTNU): Trondheim, Norway.

24. Beck, M.F., Zur Entwicklung der Eigenkorrosion von Stahl in Beton (in German), Doctoral Thesis. 2010, RWTH Aachen.

25. Bensted, J. and P. Barnes, Structure and Performance of Cements [2nd ed.]. 2 ed. 2009: Taylor \& Francis.

26. Lothenbach, B., K. Scrivener, and R.D. Hooton, Supplementary cementitious materials. Cement and Concrete Research, 2011. 41(12): p. 1244-1256.

27. Goñi, S. and C. Andrade, Synthetic Concrete Pore Solution Chemistry and Rebar Corrosion Rate in the Presence of Chlorides. Cement and Concrete Research, 1990. 20(4): p. 525-539. 
28. Garcés, P., et al., Corrosion of reinforcing steel in neutral and acid solutions simulating the electrolytic environments in the micropores of concrete in the propagation period. Corrosion Science, 2005. 47(2): p. 289-306.

29. De Weerdt, K., et al., Hydration mechanisms of ternary Portland cements containing limestone powder and fly ash. Cement and Concrete Research, 2011. 41(3): p. 279-291.

30. Gulikers, J., Experimental investigations on macrocell corrosion in chloride-contaminated concrete. Heron, 1996. 41(2): p. 107-123.

31. Glass, G.K., C.L. Page, and N.R. Short, Factors Affecting the Corrosion Rate of Steel in Carbonated Mortars. Corrosion Science, 1991. 32(12): p. 1283-1294.

32. Tondi, A., R.B. Polder, and R. Cigna, Concrete resistivity and corrosion rate of reinforcement in atmospheric concrete after one year. TNO report. 1993: TNO Building and Construction Research.

33. Angst, U., et al., Chloride induced reinforcement corrosion: Rate limiting step of early pitting corrosion. Electrochimica Acta, 2011. 56(17): p. 5877-5889.

34. Jäggi, S., Experimentelle und numerische Modellierung der lokalen Korrosion von Stahl in Beton unter besonderer Berücksichtigung der Temperaturabhängigkeit (in German), Doctoral Thesis 2001, ETH: Zürich.

35. Lambert, P., C.L. Page, and P.R.W. Vassie, Investigations of reinforcement corrosion. 2. Electrochemical monitoring of steel in chloride-contaminated concrete. Materials and Structures, 1991. 24: p. 351-358.

36. Page, C.L. and J. Havdahl, Electrochemical monitoring of corrosion of steel in microsilica cement pastes. Materials and Structures, 1985. 18((103)): p. 41-47.

37. Raupach, M., Zur chloridinduzierten Makroelementkorrosion von Stahl in Beton (in German). Deutscher Ausschuss für Stahlbeton. Vol. Heft 433. 1992, Berlin: Beuth Verlag GmbH.

38. Raupach, M. and J. Gulikers, Investigations on cathodic control of chloride-induced reinforcement corrosion, in Corrosion of Reinforcement in Concrete - Corrosion Mechanism and Protection, J. Mietz, R. Polder, and B. Elsener, Editors. 2000, EFC Publications London. p. 13-23.

39. Lataste, J.-F., Electrical resistivity for the evaluation of reinforced concrete structures, in NonDestructive Evaluation of Reinforced Concrete Structures, Vol. 2: Non-Destructive Testing Methods. 2010, Elsevier. p. 243-275.

40. Hunkeler, F., The resistivity of pore water solution - A decisive parameter of rebar corrosion and repair methods. Construction and Building Materials, 1996. 10(5): p. 381-389.

41. Elsener, B., Corrosion rate of steel in concrete - From laboratory to reinforced concrete structures, in Corrosion of Reinforcement in Concrete: Monitoring, Prevention and Rehabilitation, J. Mietz, B. Elsener, and R. Polder, Editors. 1998, Maney Publishing. p. 92-103.

42. Stern, M. and A.L. Geary, Electrochemical polarization. I. A theoretical analysis of the shape of polarization curves. Journal of the Electrochemical Society, 1957. 104(1): p. 56-63.

43. Elsener, B., Corrosion rate on reinforced concrete structures determined by electrochemical methods. Materials Science Forum 1995. 192-194 p. 857-866.

44. Andrade, C. and C. Alonso, Corrosion rate monitoring in the laboratory and on-site. Construction and Building Materials, 1996. 10(5): p. 315-328.

45. González, J.A., et al., Comparison of Rates of General Corrosion and Maximum Fitting Penetration on Concrete Embedded Steel Reinforcement. Cement and Concrete Research, 1995. 25(2): p. 257-264.

46. Elsener, B., et al., Evaluation of localized corrosion rate on steel in concrete by galvanostatic pulse technique, in Corrosion of Reinforcement in Concrete Construction, C.L. Page, P.B. Bamforth, and J.W. Figg, Editors. 1996. p. 264. 